QIJIS: Qudus International Journal of Islamic Studies

Volume 4, Issue 2, August 2016

\title{
ONE'S FACEBOOK STATUS, A REFLECTIVE SELF REPRESENTATION
}

\author{
Dewi Puspitasari \\ STAIN Pekalongan, Central Java, Indonesia \\ rafiladewi@gmail.com
}

\begin{abstract}
The phenomena of using social media in the society increases significantly. Social media is being the shifting phenomenon within communication, in which people get connected through the number of internet facilities, for the users have grown massively (Shirky 2011:1). A text as shown in the Facebook status expresses the intention and background underlying it. The writer may deny the fact, however, lexicon, markers, and the choice of a visual support in the sentence clearly reflect the hidden message of the text. From the attitude in the stance shows that the writer comes across his idea in a negative tension (attitude).
\end{abstract}

Keywords: Facebook, Reflective, Self Representation

\section{A. Introduction}

The phenomena of using social media in the society increases significantly. Social media is being the shifting phenomenon within communication, in which people get connected through the number of internet facilities, for the users have grown massively (Shirky 2011:1). To support this, Bardici (2012) states that ICT and 
digital media are the catalyst for contemporary communication. Situated as one of the latest of several waves of new media, social media have introduced new communication patterns, created new forms of expression, stimulated a wide civic participation, and so forth. Social media evolves rapidly, increases significantly, and their role changes in social and political processes. Social media are new digital media for social interaction. The concept refers to a set of internet-based applications built on the technological foundations of Web 2.0 and that enable user-generated content to be created and exchanged (Kaplan \& Haenlein 2010). To mention the forms of social media are social networking sites (e.g. Facebook), content communities (e.g. Youtube), micro-blogging (e.g. Twitter), and other mainstream software (IOS, Microsoft and Android) are samples of applications.

As social media, Facebook connects people around the world - it offers many possibilities for composing multimodal texts, not only telling one's stories in acts of verbal, but also share photos/ videos (Korpijaakko, 2015). There is a link between social media and social change, thus a general recognition comes up that social media have implications for social change due to their potential in bringing new dynamics to its underlying processes, such as public mobilization and civic engagement (Bardici, 2012). Social media are increasingly becoming an instrumental approach, and power for, social change. Any individual may reach the service, both to create movements and voice themselves, for both the good and the bad, as discussed by certain scholars, supporting that social media can be utilized for both positive and negative communication outcomes. Kim (2001) stated that Facebook generation', those who are tele-present may feel as close to us as those who are present in an embodied way. Cyberspace in general, and social networking sites in particular, have rapidly evolved into extensions of our human bodies, opening up new possibilities for us to be with one another in the digital world. Contrary, Binder, Howes and Smart (2013) mentioned that social media and other type and number of social spheres and technological features increased levels of 
social tension result. These ideas are supported by the findings from a survey study among Facebook users. Social diversity of the Facebook network predicted online tension as did the number of family members on Facebook, in contrast to work and social contacts. This tension does not necessarily imply open conflict, yet it can put a strain on networks, for example, in the form of social blunders, criticisms and so forth. Supporting this, a study by Coretty and Pica (2015) suggested that the communication protocols of commercial social networking media lead to organizational centralization and fragmentation in social movements by eroding one of the preconditions of collective identity, namely solidarity. Facebook communication protocols encourage phatic forms of communication, which are insufficient for a shared definition of the meanings of protest. Moreover, Facebook pages do not enable the formation of strong ties among users, since they privilege dialogic rather than trialogic interaction. Korpijaakko (2015) in the research reported that Facebook use is impacting society and culture life in the way people socialize and communicate with each other, read each other, see themselves, and present themselves to others. It is changing the meaning of friend and friendship, age category definitions, and news sources, and it is also improving people's social capital leading to positive psychological benefit, affecting socio-political action, while causing addictive behavior, and feelings of pressure to be on. Hence, for me, a person's Facebook status is an interesting theme to be undertaken as a research, since by reading it, we are able to understand the context underlying the text.

\section{B. A Status as a Text - One's Self Representation}

This study focuses on hidden message of a Facebook status (namely A Multimodal Discourse) into a name, a work by Halliday (1978) which is attributing the work on text - and context, for a tri-functional conceptualization of meaning (as ideational, interpersonal and textual). Halliday adds to other scholar's original tri-stratal conceptualization of meaning making as co- 
articulation of phonology, lexicogrammar and semantics, in which he describes each level as 'realizing' the next, in which there is a believe that the metafunctional components of language relates to the components of context, such that what the language is about ('linguistic ideation') is not randomly related to any kind of context, but will reflect a specific context's fields. At the same case, how the language used would absolutely locate people ('linguistic interpersonality') that will reflect a context's tenor, and how the language unfold as structured ritual ('textuality') would reflect a context's mode. Halliday's work also moved linguistics from a focus on the sentence (as was in the Chomskian tradition) towards a focus on 'text'. In this case, rather than purely and simply an analytical object, text, in Halliday's conceptualization, constitutes first and foremost 'a mode of social action' (Halliday, 1984). For short, field refers to the subject matter and it may be similar to certain uses of the term domain in computational linguistics: what is happening, to whom, where and when, why it is happening, and so on. Tenor refers to the social relation existing between the interactants in a speech situation. It includes relations of formality, power, and affect (manager/clerk, father/son). Tenor influences interpersonal choices in the linguistic system, and thereby it affects role the structures and the strategies chosen to activate the linguistic exchange, while mode describes the way the language is being used in the speech interaction, including the medium (spoken, written, written to be spoken, etc.) as well as the rhetorical mode (expository, instructive, persuasive, etc.).

Text is not only regarded in verbal acts only, it is in fact appear in some other features, multimodal ones. The two scholars, Gunther Kress and Theo van Leeuwen have considered semiotic which lead to the theory of visual communication. They point out that all texts are multimodal in the sense that spoken language is always accompanied by paralinguistic means of communication such as speech-sound, rhythm, intonation, facial expression, gesture and posture, and that written language is always also a visual arrangement of marks on a page. Language is one of a 
variety of semiotic modes available to people for creating meaning. Referring to this they suggest that modes other than language, such as visual images, have been insufficiently explored in various forms of communication. how the way in which language as well as visual images are used currently, shows marked change to the way these semiotic modes were used relatively recently. To illustrate, they consider how images, as a semiotic mode alternative to language, are used in a variety of texts, such as children's books, science textbooks and newspaper front pages (Weiss and Wodak, 2003). A facebook status often comes in written text, in plain sentence and along with visual text. Thus, as explained by Kress and Leeuwen this indicates markers, symbols on the page.

\section{Facebook Status - An Analysis}

\section{WR's Status: Jilbab / Hijab as to Cover Crime?}

A protest against the realism happens around him, WR's multimodal text, a combination of a verbal text and visual one focuses jilbab/hijab as the woman's hair cover. Written on July $2^{\text {nd }}$, WR mentioned "Religion is used as a cover (negatively) in the verbal text of 'Agama hanya dijadikan kedok - Jilbab / Hijab bukan untuk menutup aurat - Tapi hanya untuk menutupi kejahatan [Religion is only used as a cover - Jilbab / Hijab is not to close the genitals - But just to cover up the crime]. WR views that jilbab is being a trend, has losing its main function, to really cover woman's genitals body, in this case is to conceal the misconducts.

Concerning the field of a text, at a glimpse it is an informative text, however there is a bias title in 'BNN Gagalkan Penyelundupan Sabu di Balik Kerudung 4 Wanita' [BNN Bust the Sabu Smuggling Hidden Under the Veil of 4 Women], in which the voice of the news is cornering 'the veil/jilbab'. WR does not carefully select and filter that the media has unfairness in distribute the news, judged from the title of the text. In sum, from the tenor, that WR does not list any name of the reader, it implies that he does not want to listen any other's idea, he knows better than other. In term of 'standing' the lexical words tell us that WR's concentration is in 'the jilbab'for the 
aspect of 'stance' WR does not give space to the readers to disagree by providing the supporting detail of his argument (a picture and an article) supporting his belief.

WR uses mainly imperative tone in his text, and there is negative emotion in picking the words, in his theme of the sentence, he focuses "religion". He does not want to focus on 'jilbab' but trying switch to 'religion', at first; however he is clearly understood in the lexical of 'hanya dijadikan kedok' - the term 'hanya [only] brings again, negative voice in his text. In the next clause, WR places Jilbab / Hijab to unite the previous clause, and there is a question, since the text is written in bahasa Indonesia, why doesn't he choose the lexical of 'kerudung' since it is a popular word in Kamus Besar Bahasa Indonesia and acceptable in every context? Next is that his verbal text does not correlate well to the visual (picture of the women) that one woman covered his face and uncover her part of the neck as her genital. In this first text, I analyze that WR's hidden message is that he tends to over-generalize the readers who wears head-cover, no matter it is kerudung, jilbab, or hijab.

\section{WR's Status: Jilbab / Hijab is not Needed to Cover A Woman's Hair Beauty}

This multimodal text combines two modes of text - verbal and visual. Clearly understood, it is written by the FB owner to persuade the reader of not doing something, as what he believed that a female should not cover her head, since according to him, God has already gave beautiful gift - hair - to any female in the world. From the experiential viewpoint, the field of a text is at a glance a common daily status, written by a middle-aged Indonesian male, living in Europe (profile picture), created on July, 132016 (date listed), a repetitive act he often does by posting the similar topic previously. However, from tenor, it's not a mere daily status, since tenor as refers to the social relation existing between the interactants in a speech situation shows us there are certain contexts of situation, and culture underlying the text. As mentioned, the kind of text is a persuasion, from the analysis of 
personalization, standing and stance in the written text.

First, in terms of personalization, the writer does not salute the reader. It's a mix between giving information (by sharing the supporting link of picture of Arab Princess), but persuading in the end. I analyze that this written text belongs to a persuasive and instructive text as it is written by someone who puts himself as having more power than the readers of the text, without realizing that he labels himself not having equal position to others, knowing more.

For 'standing' and 'stance', the first is related to how much the writer comes across as possessing expertise and authority on the subject is clearly caught in the status of the lexical words used. From the lexical items, the choice of wordings reflects that he wants to compare two aspects, in this case: Arab and Indonesia, with his main concentration: 'the hair'. In 'stance' or how much the writer allows the reader to disagree with the content, he does not give space to the readers to disagree by providing the supporting detail of his argument (a picture and an article). He mentioned the verbal act of "Keindahan rambut seorang wanita - karunia Tuhan Yang maha Esa, yang tak perlu dibungkus \& disembunyikan" [ The hair beauty of a woman - as the bless of God the Great, no need to be wrapped \& hidden], in which the writer puts the 'the hair beauty' as the theme or the head of the clause, adding '- dash" to give stress defining it as the God's creation. As God's creation, thus he argued that the hair should not (imperatively) be hidden by not covering it.

Both attitude and modality in the stance also show that the writer comes across his idea in a negative tension (attitude). The clause of 'tak perlu dibungkus \& disembunyikan' can't be translated as 'should not ... hidden', since what is written by this writer brings negative emotion. In Bahasa Indonesia, why should he selects the lexical word of 'disembunyikan' [hidden] not just simply 'ditutupi [covered]' as having more neutral meaning, though the tension is still not neutral, and hence his status con to the contains an authoritative voice - 'no need to..' as a persuasion 
and the command of not completing something.

This text relates to the context of society, in which it is a reaction to the phenomena in the populace, that there is a different perception among scholars and ulamas, concerning jilbab. However, analyzed from the ideology underlying the text, it is not merely a plain reaction, but a protest to the condition that is: why should an Indonesian, who is not the originally the native of Arabic do something that is not done by an Arabic Princess. Dedicated to specialized readers, especially for female Moslem, this text functions as a winning text persuading and commanding through the deontic modality (in other word, the obligation to do something the text to put on the reader) - that is 'must'.

\section{3. (Jilbab/Hijab) is an oddity in Indonesia}

As in his previous status on July $13^{\text {th }}$, WR's written text in his page, again invites the reader to compare, the two conditions in Indonesia and in Arab. He takes the article of [Arabic becomes the West, Indonesia Becomes Arabic] from another reference. In this, he wants to give broadening perspective to the reader, not only relying to one site source. In this, he traps himself of picking one sample of a couple in Arab namely Prince Ameera Al Taweel, a wife of Sultan's relative as the only woman who is at now currently struggling for the right of Arabic women to not wearing jilbab. The media that WR cited is at the same case, bias in distributing the news to the readers by analyzing the title. The word of 'Arab' indicates the whole people of Arab, it is a questioned word, as Arab does not represent Islam only, since on reality, in the society there are many

The fact does not support the news, as is the text, there is a case of a Prince who is not dressed in a jilbab. The attitude in the text shows that the writer (still) deliver his idea in a negative tension (attitude) from the clause of 'satu lagi keanehan di Negara kita Indonesia yang tercinta' [one more oddity in our beloved country Indonesia]. The choice of 'oddity' brings negative sentiment means something that is weird or not normal, and when we link to the 
visual text from the article he cites, it is commonly understood that WR regards that the wearing of jilbab is simply adapting the culture from Arabic people. He should actually criticized the media, stating that what is weird is that the Princess is allowed and not being 'punished' by the law as there is a strict regulation that women should cover their genital (in public areas). 23 times being shared, this status provokes pros and contras. PD as the first commenter stated 'pembodohan dan dibodoh-bodohi' [deceived and fooled] that he agreed to WR's text, meaning that covering the body with jilbab is regarded as something fool, the same voice AA also has the matching ideology, as he mentioned everything is turned upside down, complicated.

A closer relation is shown by IB when MP mentioned that WR as the one who produced the text is the one who is weird. MP has a lower power than WR, by analyzing his sentence in question [is the one who is weird is WR (who made the status)?]. In this case, he seems wants to respect others' feeling by not using direct statement, having imperative voice as [the weird one is WR]. IB, in other case, has closer relation (tenor) to $\mathrm{WR}$, as he mentioned in a judging voice, that [WR is not weird, you are the weird one]. This sample of text is picturing the realm in society, concerning people's identity which is affected by the anxiety and confusedness of something.

YO, in his persuasive text, arguing in informal wordings lead to a conclusion that WR is the weird one, but his persuasive text is presented in a non sarcastic way. Before he judges something, he presented the description of the context, that [Islam is Islam, whether it is in Arab or in any other country, all is same. What is not same is those who hate Islam, if in Arab, syiah is 'designed', for Indonesia, 'JIL, JIN, NUSANTARA" are 'created']. He also added by adding more verbal text, [the way the text is created in the status belongs to those who hate Islam, if WR realizes that]. I might say that YO's way in making WR realized is performed in a stunning way, not in a cynical technique, not using his power, in fact he manages it. 
MPS also questions WR, untuk kesekian kalinya selalu yang dibahas masalah ini, kenapa ya?? Saya kira masih banyak tema lain perlu dibahas dan bermanfaat bagi kita semua [for many times, always this issues is discussed, I wonder why ?? I think there are many other themes to be discussed and beneficial for all of us]. From this verbal text, MPS feels he is in the same equality to WR, by asking this, both in the use of lexical items such as diction and the question marks. He makes the clause of 'for many times' as the head of his text, it indicates that WR has already published the same topic as his status in the Facebook. The lexicon of 'always' indicates he protests $\mathrm{WR}$, giving the stress that he does not like the content of the status. The same case is on the use of double '??", and 'I wonder why', as MPS believes that through the FB status, WR tries to spread something hidden, as something repetitive - that is WR's ideology concerning 'jilbab/hijab', that WR does not feel convenient with it.

However, WR through his 2 times edited reply states that he insists that he does not disfigure Islam as a religion, however he is only questioning on the culture. This editing process indicates that WR is carefully responding to others. In his first clause, he states Sebagian Saudara kita sebagai umat muslim di Indonesia suka salah mengerti dan tidak suka dikritik! [Most of our brothers as Muslims in Indonesia tends (like to) misunderstood and does not like being criticized !]. This text is based on his previous experiences that some readers protests against him. However, he locates '!' in the end of the clause indicating that it is an imperative voice, stating that WR is not happy with the responses of others who disagree with him. He clearly states, that the text is based on his opinion, not others, that is menurut saya [according to me], but he refuses to accept by continuing with emphazising in Culture with capslock - 'posting di atas, menurut saya, adalah soal BUDAYA, bukan menyangkut Soal Aqidah Agama, jadi jangan langsung dituduh menjelek-jelekkan Islam dsb' [ (what I) posted above, I think, is a matter of CULTURE, (it's) not about Aqidah Problem of Religion, so do not directly accuse me on insulting Islam, etc]. The clause of 'I 
think' signifies that WR still defends against what people advised to him, he press capital letter to give emphasis on 'the culture', in fact, jilbab matters is not a matter of culture, but it is an order from Allah, and found in Al-Quran. His resistances also can be seen in the clause 'do not directly accuse me on insulting Islam', dan certain clauses indicate his imperative voice, such as 'renungkanlah baikbaik' [think about it well], however WR tries to lower the tension by adding 'lah' in there. The rest clauses still reflect the imperative or negative emotion, from many '!!' in his text.

AS's tenor comes in an imperative tone, starting by "jangan' [don't] in jangan menyebar luaskan berita yang membenci Islam, bikin status yang lainnya yang bermanfaat buat agama kita dan buat penganutnya yang taat menjalankan syariat agama Islam, in syaa Allah dapat pahala. Aminn. Jangan sekali - kali menyinggung soal jilbab jenggot dil. Itu sudah jelas tercantum dalam Al-Quran dan hadist (jangan dianggap dongeng) [Do not spread the news that hate Islam, make the status that is more useful for our religion and for adherents who obey the law of Islam, in syaa Allah (you'll) get reward. Aminn. Never ever mention the headscarf, beard etc. They're already clear in the Quran and hadith (don't consider them to be a fairy tale)].

From this, the tenor (the social relation) shows that AS attributes himself as having equal status, on the term of address he used, the way he speaks to WR in written form. The imperative voice is found in this text, and it functions as an order. From the lexical words, AS has close social distance as his language expresses familiarity and friendliness. Analyzed from the lexical words, again, AS concludes that WR's previous facebook statuses are texts that confront to Islam. That is why he suggested WR of not doing certain acts, hence for 'standing' AS possess expertise and authority on the subject is clearly caught in the status of the lexical words used. This text pictures the reality in the society that there is an anxiety regarding jilbab existence. Jilbab is no longer to cover the genitals, but it becomes the trend in the women in Indonesia. It is still being a controversy among scholars and ulamas, and regarding this 
social cultural context, not exposing sensitive matters is a good way to respect others.

Another clause of 'jangan dianggap dongeng'[never regard them as a fairy tale' entails the context that (sometimes) some people judge that Al-Quran existed only long time ago, thus the content inside are suitable only in the era, not at present. The context of Al-Quran for some is said not linear to the current condition; in fact, this blunder thought is stated by those who haven't understood the real meaning inside the Al-Quran.

What is stated by AS Berarti orang-orang tua kita dahulu di Indonesia, yang tidak berjenggot dan tidak berjilbab di-Anggap SALAH? Dianggap BUKAN ORANG ISLAM? Bacalah juga Pendapat2 Ulama NU di Indonesia. [Does it mean the old people (the previous generations - father, mother, etc) in Indonesia, which does not wear jilbab / hijab or is obligated having a beard - considered as a WRONG act? (Are they considered NOT ISLAM ? Read also the voices of Ulamas of NU in Indonesia].

Reading WR's statement, I examine that WR gets attracted to the final text (rheme) produced by AS. In fact, AS' first focus is not in that rheme, but on the text of [Do not spread the news that hate Islam]. WR's context that his context of situation puts him on the corner, then, he defends by stating [Does it mean the old people (the previous generations - father, mother, etc) in Indonesia, which does not wear jilbab / hijab or is obligated having a beard - considered as a WRONG act?...]. WR's voice through the capslock indicates that he gives emphasis on certain words, SALAH, BUKAN ORANG ISLAM. He then adds by commanding AS to read more concerning other scholar's idea. From the tenor, it is understood that WR still puts himself higher than AS.

YO's next text indicates he wants to be more neutral, although it's impossible for someone to be objective in seeing something. YO's text is not completed yet, but he has lowering his voice, by two conditions, to respect $\mathrm{WR}$, for not losing the face, or because he does not have any supporting detail to support his statement. He should give supporting facts to bring the explanation 
to an end. In the next move, AS even lower his position by asking for apology for being regarded blaming the parents. I observe that the text of YO and AS both reflects neutral emotion, but not in the rheme of AS. Oh, maaf, saya tidak menyalahkan orang tua, makin ke sini orang - orang makin rajin belajar dan memperdalam Islam. Doakan orang Tua kita dalam kubur jangan dibawa - bawa. [Oh, sorry, I don't blame (our) parents, ..... In the rheme of the text, AR shows his persuasive text, [pray to Allah our parents who have just passed away. Don't talk negatively about them]. This text shows AR has higher equality as he commanded WR not doing something. WR, in his defensive argument, quotes the link of a scholar's opinion, mentioning 'Love your own nation, not others". Here, WR add his verbal text, [up no now, people keep and diligently learn Islam in the version of SALAFI/WAHABI (in capital letter) as the invention of the Jewish]

\section{Culture of Javanesse Woman}

The written text produced by WR, on July $19^{\text {th }} 2016$ in capital letters, giving the high tension of what he feels. WR protests on the phenomena in the society in which women changed their appearance as the changes of time. I analyze that this written text belongs to a persuasive and instructive text as it is written by someone who is previously post the issue of jilbab / hijab from June to July 2016. This text of women who are wearing the traditional cloth of Java is triggered by the context of culture and situation. The culture is on the society that changes the style from this kind of cloth to the present dress and fashion style, that is jilbab syari'e, jilboob, jilbab modis, etc. This text represents how WR who lives in Europe does not feel comfortable with the current condition. With his context of situation, in which in Europe, people think logically and secular, WR is a member of the community who is less in religious literacy. He does not agree that head scarf belongs to the order of God to protect the genital, that Al-Quran Quran mentions it clearly.

The way WR creates the verbal text indicates that he is not 
equal to the others (readers). This is an informative text, as well as a persuasive one. As someone lives abroad, his knowledge is more than others. From the attitude in the stance shows that the writer comes across his idea in a negative tension (attitude). The clause of 'Budaya berpakaian nusantara wanita Indonesia yang kita promosikan di manca negara' [the culture of Indonesian woman's dress that we promote in foreign countries], it is a big question why WR only displays the visual text that represents Javanese culture only as Indonesian traditional costumes vary.

\section{Conclusion}

A text as shown in the Facebook status expresses the intention and background underlying it. The writer may deny the fact, however, lexicon, markers, and the choice of a visual support in the sentence clearly reflect the hidden message of the text. From the attitude in the stance shows that the writer comes across his idea in a negative tension (attitude). The clause of 'Budaya berpakaian nusantara wanita Indonesia yang kita promosikan di manca negara' [the culture of Indonesian woman's dress that we promote in foreign countries], it is a big question why WR only displays the visual text that represents Javanese culture only as Indonesian traditional costumes vary. 


\section{REFERENCES}

Bardici, Minavere Vera. 2012. A Discourse Analysis of the Media Representation of Social Media for Social Change - The Case of Egyptian Revolution and Political Change, Thesis Submitted for Completion of Master of Communication for Development, Malmö University, Sweden

Binder, Jens; Howes, Andrew and Smart, Daniel. 2013. HARMONY AND TENSION ON SOCIAL NETWORK SITES. Information, Communication \& Society, 15:9, 1279-1297. http://dx.doi. org/10.1080/1369118X.2011.648949

Corettia,Lorenzo \& Picab, Daniele. 2015. The rise and fall of collective identity in networked movements: communication protocols, Facebook, and the anti-Berlusconi protest. Information, Communication \& Society. Pp. 951-966

Halliday, Michael. 1978. Language as Social Semiotic. The Social Interpretation of Language and Meaning. London: Arnold.

Idema, Rick. 2008. Multimodality, resemiotization: extending the analysis of discourse as multi-semiotic practice. http://vcj. sagepub.comu. University of New South Wales

Kaplan, AM \& Haenlein, M 2010, 'Users of the world, unite! The challenges and opportunities of social media', Business Horizons, vol. 53, no. 1, pp. 59-68.

Kim, J. 2001. Phenomenology of digital-being. Human Studies 24(1-2) 87-111

Korpijaakko, Maria Leena. 2015. Cracking Facebook, The Importance of Understanding Technology-Based Communication, Sense Publishing, Rotterdam.

Shirky, Clay. 2011. The Political Power of Social Media Technology, the Public Sphere, and Political Change Foreign Affairs. 
Sua, Leona Yi-Fan Michael; Lianga, A. Cacciatoreb; Brossarda, Dominique, Scheufelea, Dietram and Xenosc, Michael A. 2016. Information, Communication \& Society. Analyzing public sentiments online: combining human- and computerbased content analysis 